\title{
Is endocan correlated to ARDS severity or an epiphenomenon of thrombo-embolic disease in COVID
}

\author{
Patrick M. Honore ${ }^{1,3^{*}}$, Sebastien Redant ${ }^{1}$, Thierry Preseau ${ }^{2}$, Bogdan Vasile Cismas ${ }^{2}$, Keitiane Kaefer, \\ Leonel Barreto Gutierrez, Sami Anane, Rachid Attou, Andrea Gallerani and David De Bels
}

Keywords: Endocan, ARDS severity, Pulmonary embolism

With great interest, we read the recently published paper by Pascreau et al. concluding that a high blood endocan profile during COVID-19 distinguishes moderate from severe acute respiratory distress syndrome (ARDS) [1]. In a recent study including 46 patients with a diagnosis of pulmonary thromboembolism (PTE) and a control group of 25 healthy individuals [2], there was a significant difference in the serum endocan levels between the patients and the control group (321.93 ng/l and $192.77 \mathrm{ng} / \mathrm{l}$, respectively; $p<0.030$ ) [2]. Endocan is likely a good marker for PTE, a frequent phenomenon in COVID-19 [3]. In a prospective postmortem evaluation of 735 consecutive SARS-CoV-2-associated deaths, on autopsy $(n=283)$ it was found that the majority died of pneumonia and/or diffuse alveolar damage (73.6\%) but thromboses were found in $39.2 \%$ and PTE in $22.1 \%$ [3]. Another study demonstrated significant associations between PTE and not only mechanical ventilation $(\mathrm{OR}=3.71$, 95\% CI 2.57-5.36), but also intensive care unit admission $(\mathrm{OR}=2.99,95 \% \mathrm{CI} 2.11-4.23)$, circulating $\mathrm{D}$-dimer [mean difference $(\mathrm{MD})=5.04 \mu \mathrm{g} / \mathrm{mL}, 95 \%$ CI 3.67-6.42) and c-reactive protein $(\mathrm{CRP})(\mathrm{MD}=1.97 \mathrm{mg} / \mathrm{dL}, 95 \% \mathrm{CI}$ 0.58-3.35) [4]. Those characteristics are similar to those found in the Pascreau study (high CRP, high D-dimers and mechanical ventilation in ARDS COVID patients)

*Correspondence: Patrick.Honore@CHU-Brugmann.be

${ }^{1}$ ICU Department, Centre Hospitalier Universitaire Brugmann, Brussels, Belgium

Full list of author information is available at the end of the article
[1]. As there is no indication they excluded PTE in their patient cohort, it seems plausible that Pascreau et al. are describing the consequences of thromboses and PTE in ARDS COVID patients [1]. The explanation for endocan levels is therefore more likely to be found here than as a marker of ARDS severity.

\section{Abbreviations \\ ARDS: Acute respiratory distress syndrome; PTE: Pulmonary thromboembolism.}

\section{Acknowledgements \\ None.}

\section{Authors' contributions}

PMH, SM, SR and DDB designed the paper. All authors participated in drafting and reviewing. All authors read and approved the final version of the manuscript.

\section{Funding}

None.

\section{Availability of data and materials}

Not applicable.

\section{Declarations}

Ethics approval and consent to participate Not applicable.

Consent for publication Not applicable.

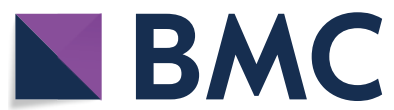

(c) The Author(s) 2021. Open Access This article is licensed under a Creative Commons Attribution 4.0 International License, which permits use, sharing, adaptation, distribution and reproduction in any medium or format, as long as you give appropriate credit to the original author(s) and the source, provide a link to the Creative Commons licence, and indicate if changes were made. The images or other third party material in this article are included in the article's Creative Commons licence, unless indicated otherwise in a credit line to the material. If material is not included in the article's Creative Commons licence and your intended use is not permitted by statutory regulation or exceeds the permitted use, you will need to obtain permission directly from the copyright holder. To view a copy of this licence, visit http://creativecommons.org/licenses/by/4.0/. The Creative Commons Public Domain Dedication waiver (http://creativeco mmons.org/publicdomain/zero/1.0/) applies to the data made available in this article, unless otherwise stated in a credit line to the data. 


\section{Competing interests}

The authors declare to have no competing interests.

\section{Author details}

${ }^{1}$ ICU Department, Centre Hospitalier Universitaire Brugmann, Brussels, Belgium. ${ }^{2}$ ED Department, Centre Hospitalier Universitaire Brugmann, Brussels, Belgium. ${ }^{3}$ CU Department, Centre Hospitalier Universitaire Brugmann-Brugmann University Hospital, Faculty of Medicine „U ULB University, Place Van Gehuchtenplein, 4, 1020 Brussels, Belgium.

Received: 12 November 2021 Accepted: 15 November 2021

Published online: 14 December 2021

\section{References}

1. Pascreau T, Tcherakian C, Zuber B, et al. A high blood endocan profile during COVID-19 distinguishes moderate from severe acute respiratory distress syndrome. Crit Care. 2021;25(1):166. https://doi.org/10.1186/ s13054-021-03589-3.

2. Güzel A, Duran L, Köksal N, et al. Evaluation of serum endothelial cell specific molecule-1 (endocan) levels as a biomarker in patients with pulmonary thromboembolism. Blood Coagul Fibrinolysis. 2014;25(3):272-6. https://doi.org/10.1097/MBC.0000000000000071.

3. Fitzek A, Schädler J, Dietz E, et al. Prospective postmortem evaluation of 735 consecutive SARS-CoV-2-associated death cases. Sci Rep. 2021;11(1):19342. https://doi.org/10.1038/s41598-021-98499-3.

4. Gómez CA, Sun CK, Tsai IT, et al. Mortality and risk factors associated with pulmonary embolism in coronavirus disease 2019 patients: a systematic review and meta-analysis. Sci Rep. 2021;11(1):16025. https://doi.org/10. 1038/s41598-021-95512-7.

\section{Publisher's Note}

Springer Nature remains neutral with regard to jurisdictional claims in published maps and institutional affiliations.

- fast, convenient online submission

- thorough peer review by experienced researchers in your field

- rapid publication on acceptance

- support for research data, including large and complex data types

- gold Open Access which fosters wider collaboration and increased citations

- maximum visibility for your research: over 100M website views per year

At BMC, research is always in progress.

Learn more biomedcentral.com/submissions 